Wrocławskie Studia Wschodnie

23 (2019)

Wydawnictwo Uniwersytetu Wrocławskiego

DOI: $10.19195 / 1429-4168.23 .1$

MareK NALEPA

ORCID: 0000-0001-9632-1033

Uniwersytet Rzeszowski

\title{
Granice państwowe, narodowe i kulturowe w prozie wspomnieniowej Juliana Ursyna Niemcewicza
}

\section{Niemcewiczowska ,smuga cienia”}

Adam Jerzy Czartoryski w Żywocie Juliana Ursyna Niemcewicza zauważa, że wydarzenia z początku lat dziewięćdziesiątych XVIII wieku, a więc zawiązanie konfederacji targowickiej, upadek Konstytucji 3 maja i przymusowa emigracja, położyły się cieniem na biografii autora Powrotu posła, do 1792 roku w miarę spokojnego i uporządkowanego.

Jeszcze nie był doszedł do połowy lat życia swego, ledwo ich liczył 30 i kilka, a już skończyły się dla niego dni wesołe, spokojne, szczęśliwe. Odtąd nie będzie znał w życiu, jak żale, smutki, niepokoje, okropne więzienie, wygnanie, ubóstwo, oddalenie od rodziny i przyjaciół; omylne nadzieje, same powody do rozpaczy będą jego udziałem ${ }^{1}$.

Wejście w „smugę cienia” wraz z wyjazdem do Lipska, a następnie do Wiednia (1792), Florencji (1793) i Rzymu (1794) stanowiło też wyraźną cezurę w życiu podróżniczym pisarza, a jak wiadomo, należał on do grupy Polaków przełomu XVIII i XIX stulecia wyjątkowo ciekawych świata, o czym doskonale sam wiedział i zaświadczył zapis w pamiętnikach: „Z dzieciństwa pałałem niepohamowaną chęcią zwiedzania obcych krajów"2. Jego peregrynacje miały różnoraką motywację: od interesów majątkowych i rodzinnych, lustracji i misji związanych z pełnionymi funkcjami i stanowiskami, poprzez zesłanie, emigrację i ucieczkę, po turystykę. Uformowany jednak w środowisku ludzi gotowych do służby publicznej i włączenia się w dzieło reformowa-

1 Żywot J.U. Niemcewicza przez X. Adama Czartoryskiego, Berlin-Poznań 1860, s. 78.

2 J.U. Niemcewicz, Pamiętniki czasów moich, oprac. J. Dihm, t. 1, Warszawa 1957, s. 153.

Wrocławskie Studia Wschodnie 23, 2019

(C) for this edition by CNS 
nia państwa, z których przynajmniej kilku otwarcie drwiło z oświeceniowej podróżomanii, próbował tuszować jej bezużyteczność społeczną ${ }^{3}$ swoistą filozofią własnych zagranicznych wojaży. Przy okazji drugiego wyjazdu do Włoch w 1793 roku stwierdził mianowicie, że podejmuje go, kierując się nie własnymi potrzebami, ale pragnieniem poszerzenia wiedzy Polaków o Półwyspie Apenińskim:

Dojrzalszy, usposobieńszy, niźlim był przed lat dziesięcią, postanowiłem nie zabawę dla siebie, lecz pożytek jaki dla kraju mego z podróży tej przynieść; przedsięwziąłem w ojczystym języku porządnie Włochy opisać4

Zauważony przez Czartoryskiego przełom w życiu Niemcewicza można rozpoznać w opisach granic, kordonów, komór i kamer celnych, rogatek, miejsc wielokrotnie przez niego przekraczanych. W pamiętnikach i innych relacjach z podróży odbytych przed 1795 rokiem kwituje je zwykle krótką wzmianką ${ }^{5}$ lub pomija zupełnie ${ }^{6}$, natomiast po tej dacie skrupulatnie odnotowuje miejsca kontroli granicznej i co więcej, opisowi takiemu z reguły towarzyszy emocjonalny komentarz — sentymentalny i nostalgiczny albo złośliwy i ironiczny. Raz tylko pozwala sobie na upływ „,kordonowych emocji” w okresie „dni wesołych, spokojnych, szczęśliwych”, aczkolwiek nie przy przekraczaniu granicy, a przy otarciu się o nią w Satanowie. Stało się to w czasie podróży ${ }^{7} \mathrm{~W} 1780$ roku w orszaku generała ziem podolskich, który lustrował dobra Czartoryskich na Wołyniu, Podolu i Ukrainie, a przy okazji próbował odciąć się od bolesnych wspomnień dotyczących tragicznie zmarłej

${ }^{3}$ Ostatnio szerzej temu problemowi przyjrzał się amerykański socjolog Dean MacCanell w książce Turysta. Nowa teoria klasy próżniaczej, przeł. E. Klekot, A. Wieczorkiewicz, Warszawa 2002.

${ }^{4}$ J.U. Niemcewicz, Pamiętniki czasów moich, oprac. J. Dihm, t. 2, Warszawa 1957, s. 63. W innym miejscu zanotował: „Czytającemu te pamiętniki moje, częste podróże, swobodne zabawy, zdawać się będzie, żem chodził drogą wonnymi kwiatami usłaną; niech wie atoli, że w obcych krajach, porównując kwitnienie i zamożność ich z ujarzmieniem i ubóstwem naszym, w domu, patrząc na dumne przewodzenia Moskwy nad tronem i narodem, ileż piołunów lało się w kielich wesela mego! Mimo młodości, w której wszystko tak łatwo jest pogodnym, chmury smętności nieraz otaczały moje skronie" — ibidem, t. 1, s. 244.

${ }^{5}$ Na przykład „W miasteczku zwanym Pont Beau Voisin wjechałem do Francji” — ibidem, t. 1, s. 214.

6 Zdarza mu się odnotować ,inność” kraju, ale nie ma ona nacechowania cywilizacyjnego (Europa-Rosja); jej punktem orientowania nie są więc „sztuczne”, jak je widział Niemcewicz, porozbiorowe granice ojczyste, a transgraniczność ukształtowana w ciągu stuleci i rozciągana na całe przestrzenie państwowe. Takie obserwacje towarzyszą mu na przykład po dopłynięciu do Anglii: „Przejeżdżałem z Niemiec do Włoch, z Włoch do Francji, nigdzie jednak sprzeczność we wszystkim dwóch krajów sąsiedzkich tak mnie nie uderzyła jak na wstępie do Anglii. Niebo, kraina, domy, ludzie, charaktery ich, obyczaje, wszystko tu inne" — ibidem, t. 1, s. 227.

${ }^{7}$ Zanotował w pamiętnikach: „W podróży tej zwiedziłem najpiękniejsze, najżyźniejsze prowincje ojczystej ziemi mojej" — ibidem, t. 1, s. 127.

Wrocławskie Studia Wschodnie 23, 2019

(C) for this edition by CNS 
córki Teresy. Wzdłuż Zbrucza przepływającego przez Satanów po pierwszym rozbiorze przebiegała linia demarkacyjna między Polską a Austrią. Tak ją widział poeta:

wjechaliśmy na Ruś Czerwoną, dziś Galicją przezywaną. Z jakąż boleścią postrzegłem na drugiej stronie Zbrucza utkwione drapieżne orły austriackie. Pierwszy raz ujrzałem jedną z części rozćwiartowanej nieszczęsnej Polski naszej. Na spojrzenie to zalało się serce moje żalem i nienawiścią ${ }^{8}$.

Wczesne wojaże zagraniczne, którym towarzyszyły przejazdy przez granice państwowe, Niemcewicz odbył w towarzystwie Adama Kazimierza Czartoryskiego. Generał ziem podolskich, zabierając go z sobą albo wysyłając $\mathrm{z}$ innymi osobami w podróże po Europie, miał w tym pewien plan. Chciał mianowicie, aby wyjazdy te ukształtowały Niemcewicza na sposób oświeceniowy, rozciągnęły jego horyzonty myślenia, nauczyły manier, otworzyły go na nowoczesność, wyostrzyły świadomość potrzeby reform politycznych, a także „rozszerzały i wydoskonaliły jego zdolności”, w tym te literackie. Z kolei Niemcewicz chętnie z tej możliwości, i innych — złożonych mu przez Stanisława Sołtyka i Stanisława Potockiego — korzystał.

Za granicę po raz pierwszy wyjechał w 1780 roku (zwiedził między innymi Holandię), następnie w latach 1783-1785 odbył podróże do Włoch, Sycylii, Malty, Francji, Anglii, Holandii oraz Niemiec, a od 1781 roku kilkakrotnie przyjeżdżał do Wiednia. W latach 1787-1788 przebywał w Londynie i Paryżu w towarzystwie Stanisława Kostki Potockiego. Obaj wrócili pospiesznie do kraju wiosną pamiętnego 1788 roku, co Niemcewicz odnotował w drobiazgu poetyckim:

\footnotetext{
Zniknie Paryż ulubiony

I te lekkich grotów blizny,

A człek ze snu obudzony,

Westchnie do miłej ojczyzny:

„Innym tak lube siedliska,

My bez żałości porzucim..."10
}

\section{Więzienie i granica wolności}

Po likwidacji państwa polskiego Niemcewicz (wraz z Tadeuszem Kościuszką) jako pierwszą przekroczył granicę rosyjsko-szwedzką. Miało to miejsce 26 grudnia 1796 roku po pobycie w więzieniu moskiewskim. Myślał wprawdzie o powrocie w rodzinne strony i zajęciu się gospodarstwem, ale przemogły go

\footnotetext{
8 Ibidem, t. 1, s. 134.

9 Żywot J.U. Niemcewicza..., s. 27.

${ }^{10}$ Cyt. za: ibidem, s. 30.
}

Wrocławskie Studia Wschodnie 23, 2019

(C) for this edition by CNS 
prośby i stan zdrowia Naczelnika. Wraz z nim udawał się na kilkuletni pobyt do Stanów Zjednoczonych. Opuszczenie granic Imperium Rosyjskiego Niemcewicz skomentował następująco:

Z jakim wzruszeniem ujrzeliśmy się na ziemi szwedzkiej: wprawdzie więzy nasze były już zerwane, jednakże jeszcześmy dotąd ciągnęli za sobą kawałki łańcucha; teraz zdawało się nam, żeśmy ostatnie jego ogniwa na drugim brzegu rzeki zostawili. Uściskaliśmy się wzajemnie ze łzami w oczach; był to ten sam kraj, ta sama pora roku, jednak wszystko inną dla nas przybrało postać. Krajobraz zdawał nam się weselszy, domy ładniejsze, ludzie śmiało na nas spoglądali i jak z bliźnimi rozmawiali. Wyrwałem się więc z twych szponów, Rosjo! sprawczyni wszystkich nieszczęść mojej Ojczyzny i kraju, gdziem przez dwadzieścia sześć miesięcy jęczał w najokropniejszym więzieniu, z którego nigdy nie byłbym wyszedł, gdyby śmierć nie była wydarła berła z rąk Katarzyny, aby je przenieść w dłonie dobroczynne Pawła $\mathrm{I}^{11}$.

Przekraczanie granicy rosyjskiej $\mathrm{w}$ takim stanie ducha będzie swoistą normą u Polaków w okresie studwudziestotrzyletniej niewoli ${ }^{12}$. Niemcewicz doskonale wychwycił ów moment wyrwania się z sideł despotyzmu i barbarzyństwa, jak twierdził, niszczących odczucie godności osobistej i deprecjonujących wszelkie idee, jakimi człowiek żyje w poczuciu sensu i przydatności społecznej oraz narodowej. Uwagi Rufina Piotrowskiego, powstańca, emisariusza, konspiratora, który w 1846 roku podjął się ucieczki z Syberii (zakończonej sukcesem), jak najbardziej realizują ten paradygmat. Tak opisał on nielegalne przekroczenie granicy rosyjsko-pruskiej:

O, jakże czułem się szczęśliwym i spokojnym, będąc już za granicą! Ciężkie brzemię obawy, cierpień i smutku przez sześć miesięcy ciągle mnie tłoczące, zdawało się, że spadło z mych piersi; czułem się wesołym, rześkim i pełnym nadziei: ledwie sam sobie wierzyć mogłem, że

${ }^{11}$ J.U. Niemcewicz, Podróże po Ameryce 1797-1807, z rękopisu wydała, wstępem i objaśnieniami opatrzyła A. Wellman-Zalewska, red. E. Kipa, Wrocław-Warszawa 1959, s. 10-11.

${ }^{12}$ Podobne przykłady podaję w książce Porozbiorowe migracje $w$ literaturze późnego oświecenia. Studia nad wybranymi tekstami, Rzeszów 2018, rozdz. Granice obcości. Ku przestrzeni wykorzenienia i niewoli, s. 113-124. Niezależnie od nich warto przytoczyć fragment gawędy Leona Zienkiewicza opisujący przekroczenie przez jej narratora granicy Rosji i Kongresówki w Brześciu-Terespolu: „Przez błota, bagna, brody, groble, piaski, kamienie i puszcze jechaliśmy drogami najgorszymi i często bez dróg prawie ku granicy do Brześcia Litewskiego. Przejazd z Brześcia do Terespola przez granicę i za granicę był dla mnie niewidzianą, ledwie dotąd zasłyszaną nowością. Inne znaki, godła barwy; inny lud, inna mowa, inne stroje, zwyczaje, obyczaje, zdało mi się, inne - czystsze, lżejsze, świeższe powietrze, inna cała ziemia i całe niebo, i nie było to przywidzenie ani złudzenie zmysłów. Droga bita, po której jak po toku po raz pierwszy jak wyszedł z rąk Stworzyciela swojego toczył się z zadziwieniem rączo nasz powóz, konie rześko kroczące i jak gdyby parskające z radości, że w błocie ani w piasku po kolana nie brodza, jasne biało czerwone słupy i poręcze przydrożne, łąki i lasy zieleńsze i lepiej utrzymane, pola lepiej uprawne, dwory okazalsze, wsie porządniejsze, karczmy i zajazdy schludniejsze, miasta i miasteczka murowane i brukowane, kościoły wspanialsze, wieże wynioślejsze, lud wreszcie w ogólności żywszy, śmielszy, weselszy, swobodniejszy, śpiewający, skaczący - wszystko to razem i na raz przez oczy wpadające do duszy musiało oczywiście rozbudzać mniej odpowiednie do zewnętrzności uczucia, wzruszenia i marzenia" — idem, Wieczory Lacha z Lachów, czyli opowiadania przy kominku starego literata polskiego, Lipsk 1864, s. 194.

Wrocławskie Studia Wschodnie 23, 2019

(C) for this edition by CNS 
już byłem w Prusach [...]. Wyszedłszy za miasto i oddaliwszy się od niego na dość wielką odległość, położyłem się na spoczynek w sosnowym lesie. Jakże ten spoczynek był dla mnie błogim, a sen pokrzepiającym, nowa nadzieja we mnie wstąpiła, swobodniej oddychać zacząłem, nowego nabrałem życia, a raczej się odrodziłem. Pod tym rosyjskim, okrutnym rządem zdaje się, że krew w naszych żyłach, że uczucia w sercu, te życie duszy, że nawet powietrze, którem oddychamy, są w więzach i więzieniu. Bóg tylko w surowej swej sprawiedliwości, a szatan w zaciętej zemście, pierwszy jako karę za grzechy, drugi aby popchnąć do grzechu, mogą na ludzkość podobny rząd sprowadzić, a raczej nim ją jakby zarazą dotknąć. W tym rządzie carskim, w jego duchu, jego ustawach jest coś tak zabójczego dla czującego i myślącego człowieka, iż jeżeli się nie zniży i nie spodli aż do stanu nierozumnego bydlęcia, jeżeli zechce, co mówię, jeżeli może czuć i zachować swą godność, to albo zostać musi męczennikiem swych uczuć i swojego poznania, albo zwątpić o wszystkim ${ }^{13}$.

Niemcewicz podkreśla wszelako, iż pomimo wyrwania się ze szponów Rosji i oddychania wolnym powietrzem na ziemi szwedzkiej on i Naczelnik mieli poczucie dźwigania z sobą kawałków niewolniczego łańcucha. Chodziło zapewne o świeżą pamięć własnych losów oraz losów Polski, co w pamiętnikach i dziennikach pisanych za granicą wielokrotnie będzie jeszcze powtarzał. Rufin Piotrowski twierdzi z kolei, iż prawdziwą swobodę poczuł dopiero po przekroczeniu granicy prusko-francuskiej:

przybyłem wieczorem do Kehl, skąd i omnibusem wjechałem do Strasburga, gdzie przy wjeździe wcale nikogo o pasport nie pytano; byłem jeszcze niepewnym, pókim nie wjechał do Francyi. Trudno sobie wyobrazić, jakem się ucieszył, gdym ujrzał czerwone spodnie francuskich żołnierzy na granicy będących, tu dopiero swobodnie odetchnąłem, tu dopiero rzekłem do siebie: Tu na koniec jestem zupełnie wolnym. W uniesieniu mej radości, gdyby przyzwoitość i okoliczności mi dozwoliły, najserdeczniej byłbym uściskał, ucałował pierwszego lepszego żołnierza Francuza; tyle wolność prawdziwa ma dla nas powabu, takie przynajmniej na mnie wywarła wrażenie, na mnie tak długo, ciągle, i srogo prześladowanego od losu, i żyjącego w męczącej obawie być co chwila schwytanym i oddanym Moskalom ${ }^{14}$.

Ale uwagi autora Listów litewskich o opuszczeniu Imperium Rosyjskiego są również na wskroś uniwersalne, jeśli przyjmiemy, że podobne wrażenia przy opuszczaniu imperium carów towarzyszyły Europejczykom z Zachodu. Można by rzec, że Niemcewicz wyjeżdżał z Rosji z myśleniem na wskroś francuskim, gdyż zadziwiająco jego refleksje współbrzmią choćby z opiniami markiza Astolphe'a de Custine ${ }^{15}$. Ponadto podobny ton doznań można rozpoznać w tłumaczonych przez Ksawerego Godebskiego dziennikach Franciszka Augusta Belcoura, pułkownika francuskiego w służbie konfederacji barskiej, który ponad trzy lata spędził na zesłaniu w Tobolsku. Zachłyśnięcie się autora

13 R. Piotrowski, Pamiętniki z pobytu na Syberii, t. 1, Poznań 1860, s. 228-229.

14 Ibidem, s. 274-275.

15 A.L.L. de Custine, Listy z Rosji. Rosja w 1839 roku, przeł. K. Czermińska, Londyn-Warszawa 1988.

Wrocławskie Studia Wschodnie 23, 2019

(C) for this edition by CNS 
wolnością po przekroczeniu granicy rosyjskiej także w tym wypadku miało dramatyczny wymiar duchowy ${ }^{16}$ :

Uczułem dopiero rzetelną uciechę wolności, kiedym się już zapewnił, że już w kraju rosyjskim nie jestem; uczułem ją tak żywo, że niemal odchodziłem od siebie. Wzruszenie moje tak było gwałtowne, że lękałem się stracić tę trochę zdrowego rozsądku, które od przyrodzenia i przez wychowanie dostałem ${ }^{17}$.

\section{Bunt i mroczne przeczucia}

Emocjonalny stosunek Niemcewicza do nowych granic sąsiadów Polski brał się z przekonania, że rozbiory były aktem przemocy i zdrady — drastycznie rozrywały wspólnotę narodową kształtowaną przez wieki, która dzięki reformom miała stać się monolitem zapładniającym umysły oświeconych władców Europy do podobnych działań. Tymczasem Rzeczpospolita została wchłonięta w struktury administracyjne o tradycjach despotycznych i tyrańskich, a w wypadku Rosji dodatkowo barbarzyńskich. W związku z tym Niemcewicz jako jeden z pierwszych poetów polskiego oświecenia dostrzegł $\mathrm{w}$ rozbiorach, a więc $\mathrm{w}$ bezprawnym ustanowieniu nowych granic, zagrożenie dla języka narodowego czy w ogóle tak zwanej substancji wspólnotowej — etnicznej, gdyż także jako jeden z pierwszych twórców tej epoki, obok Józefa Morelowskiego ${ }^{18}$, przewidywał, że Polacy z różnych zaborów będą

16 Życie w Rosji było swoistym miernikiem wolności i szczęścia poza nią, zwłaszcza dla Polaków powracających do ojczyzny z zesłania lub niewoli. Wraz z przekroczeniem granicy Imperium Rosyjskiego zmieniała się dusza, ożywiały myśli i tęsknoty. Jak zauważył Eustachy Iwanowski, „ludzie i wyższego ukształcenia, panowie szlachta zacnych i starożytnych domów, pieszo przeszli całe rosyjskie cesarstwo, a kiedy się któremu z nich udało przez Dniepr przeprawić, i minąć granicę, wtedy w duszy jego nieporównana, nieopisana nigdy radość, przewyższyła w jednej chwili, wszystkie wieloletnie cierpienia! Polska, stawała się wówczas dla nich to samo, co Niebo, szczęścia Królestwo. Kto był lub jest w tułactwie, na wygnaniu, w niewoli, ten tylko może pojęć i zrozumieć ich uczucia, ich szczęście!" - Wspomnienia narodowe przez Eu.....go Helleniusza, Paryż 1861, s. 350.

17 T. de Belcour, Dziennik oficera francuskiego, w stużbie konfederacji barskiej, pojmanego przez Moskali i zasłanego w Sybir, przeł. K. Godebski, Lwów 1866, s. 140.

18 Jezuita połocki w Trenie VI. Do matek polskich pisał:

„Cóż, gdy się między sobą wasze zwaśnią wrogi?

O, jaki waszych dzieci los napotka srogi!

Każą im w świętokradzkie iść sromotne wojny -

$\mathrm{Z}$ jednej i z drugiej strony stanie Polak zbrojny.

Przyjaciel w przyjaciela swego piersi strzeli,

Coich wróg, granicami nowymi oddzieli.

Brat bratu utnie głowę, a matce w frasunku

Wróg ją z srogiej litości pośle w podarunku" - J. Morelowski, Wiersze ..., oprac. E. Aleksandrowska, Wrocław 1983, s. 38.

Wrocławskie Studia Wschodnie 23, 2019

(C) for this edition by CNS 
w przyszłości strzelać do siebie jako zaciekli wrogowie. Obawy te towarzyszyły polskim pisarzom przez cały okres niewoli, a o Polaku strzelającym w pierś Polaka pisał jeszcze Edward Słoński - legionista i uczestnik wojny z bolszewikami w 1920 roku. W przypadku Niemcewicza były to wnioski płynące między innymi z obserwacji poczynionych w czasie zagranicznych podróży. Oto wymowna notatka z wyjazdu do Wiednia, dotycząca Czechów, którzy po klęsce na Białej Górze (1620) dostali się pod wpływy absolutyzmu habsburskiego; zaraz też zmuszono ich do rekatolizacji, czego dalszą konsekwencją była germanizacja niemal całej szlachty i mieszczaństwa u południowych sąsiadów Polski:

Z żalem widziałem, jak Czesi, pobratymcy nasi, usiłowaniem rządu coraz bardziej przemieniają się w Niemców; szlachta już nie umie ojczystego języka naszego. Niestety — pomyślałem sobie — tak będzie i z nieszczęsną Polską naszą: dźwięk mowy naszej w poczciwych tylko zostanie się rolnikach ${ }^{19}$.

To wszystko sprawiło, że Niemcewicz kontestował granice rozbiorowe, z trudem i w kłopotach je przekraczał (szczególnie linie rosyjskie). Wytrwale bowiem trzymał się przyjętej zasady, iż obrysy Rzeczypospolitej ustanowili władcy piastowscy i jagiellońscy. Tak więc na żadne ich zawężanie do 1793 roku nie zgadzał się, w związku z czym oczywiście nie zaakceptował ostatniej odsłony tego dramatu — utraty granic państwowości dokonanej trzecim aktem rozbiorowym. W wielu miejscach prozy wspomnieniowej dawał świadectwo tego buntu obywatelskiego lub raczej anarchii, gdyż nigdy nie pogodził się z myślą, że został „na zawsze Rossyjczykiem”.

Trzeba też pamiętać, że likwidacja Rzeczypospolitej, która w bolesny sposób dotknęła patriotycznie myślących Polaków, w tym Niemcewicza, doprowadziła do swoistego porozbiorowego kryzysu kartograficznego. Mapa, mająca z reguły znaczenie praktyczne, była i jest przede wszystkim ważnym kodem integrującym; tak jak hymn czy symbole narodowe zespala i ogniskuje chronologię trwania w ikonie przestrzeni zbiorowej ${ }^{20}$. Pod tym względem w dziewiętnastowiecznej Europie Polska wydawała się jedynie konstruktem mentalnym, jakąś mglistą Atlantydą. W 1888 roku genialny piętnastolatek Alfred Jarry napisał farsę Ubu Król, czyli Polacy, którą otwiera znamienna lokalizacja akcji wydarzeń: „w Polsce, czyli nigdzie”. Rozbicie terytorialne spowodowane rozbiorami pociągało za sobą już nie tylko różne kryzysy natury świadomościowej i tożsamościowej, lecz skutkowało także związanymi z nimi aporiami językowo-nazewniczymi i estetyczno-wizualnymi. Brakowało zasady porządkującej antropologiczno-kulturową przestrzeń niegdysiejszej Rzeczypospolitej. Z wiel-

19 J.U. Niemcewicz, Pamiętniki czasów moich..., t. 2, s. 61.

20 Zob. J. Winiarski, W przestrzeni kulturowej poezji polskiej (pejzaże antropologiczne z wieków dawnych i współczesne). Studia i szkice, Kraków 2017, s. 398-401.

Wrocławskie Studia Wschodnie 23, 2019

(C) for this edition by CNS 
kim wyczuciem taką możliwość — kryzysu toponimicznego i kartograficznego — przewidział już w 1795 roku Józef Morelowski, autor Trenu III. Na widok mapy Królestwa Polskiego, pisząc w poruszającej apostrofie:

Kraju wielki, zmieszczony na tej szczupłej karcie!

Maszli iść jak ten wątly papier na rozdarcie,

Co go trzymam w mym ręku, a łzy me rzęsiste

Piszą na nim trzech wrogów granice troiste? ${ }^{21}$

Niemcewicz wymazanie Polski z map Europy traktował w zbliżony sposób, stąd jego manifestacje niechęci, mniej lub bardziej zawoalowane, wobec rozbiorowej i porozbiorowej geotopografii. W swoich pamiętnikach na przykład dwukrotnie w identycznym brzmieniu używa określenia „Ruś Czerwona, dziś Galicją zwana". Pierwszy raz w związku z podróżą na Kresy w 1780 roku: „Przez Satanów wjechaliśmy na Ruś Czerwoną, dziś Galicją zwaną,"22. Po raz drugi w tytule jednej z relacji wędrówek po Polsce przedsiębranych w latach 1811-1827. Brzmi on Podróż na Ruś Czerwona, dziś Galicja zwana, w roku 1820. W dopowiedzeniu „dziś Galicją zwaną” wyraźnie pobrzmiewa duch kontestacji i napięcie w myśleniu o przeszłości i teraźniejszości. Ów dysonans onomastyczny zostaje dodatkowo wzmocniony już na początku zapisu wspomnieniowego:

Doświadczywszy lata zeszłego, jak niedogodną jest rzeczą puszczać się w podróż w czasie ciężkich upałów, wcześniej wybrałem się tej wiosny. Ruś Czerwona, zdobycz Kazimierza Wielkiego, najpiękniejsza z polskich niegdyś prowincji, po zaborze swym Galicją przezwana, stała się celem historycznych zwiedzań moich ${ }^{23}$.

Określenia: „Dziś Galicją zwaną”, „po zaborze swym Galicją przezwana” sugerują nominalno-administracyjny charakter wprowadzonej przez zaborcę austriackiego nazwy na tereny odłączone od Polski w 1772 i 1795 roku. Z trudem przyjmowała się ona wśród mieszkańców tej prowincji ${ }^{24}$, nie mówiąc

21 J. Morelowski, op. cit., s. 34.

22 Ibidem, t. 1, s. 134.

23 Juliana Ursyna Niemcewicza podróże historyczne po ziemiach polskich, między rokiem 1811 a 1828 odbyte, Paryż-Petersburg 1858, s. 416.

${ }^{24}$ Wyraźne opory nazewnicze dotyczące Galicji da się odczuć w wierszu Onufrego Bieniowskiego pod tytułem Opis dalszy rozbioru Królestwa Polskiego za panowania i rządów Stanisława Ciołka Poniatowskiego, siedzacego na tronie, jako też różnych awantur dziejacych się w tym kraju polskim, jako $i$ w innych strony Europy [...], zaczęty 1795 a skończony roku 1800. Oto krótki jego fragment:

„Ojczyznę z Orłem Białym w sztuki podzi[e]lili.

Do czego się przyłożył król polski przez zmowy,

Odstąpił tronu swego z miłości carowy.

Sam u niej niewolnikiem — wolał ująć gembie

Niźli polskie utrzymać granice w obrębie.

Z jej ręki dziś wyglądać musi zysku swego,

Wrocławskie Studia Wschodnie 23, 2019

(C) for this edition by CNS 
o Niemcewiczu, dla którego wciąż stanowiła ona Ruś Czerwoną, obejmującą w przeszłości ziemię sanocką, przemyską, chełmską, bełską, halicką i lwowską. Pamiętajmy jednak, że Galicja nie była li tylko zamiennikiem toponimicznym Rusi Czerwonej, jak tego chce pisarz - zagrabiona przez Austriaków część Polski posiadała bowiem znacznie rozleglejsze terytorium, natomiast Ruś Czerwona odpowiadała swym zasięgiem raczej granicom województwa ruskiego, istniejącego nieprzerwanie od 1434 roku do pierwszego rozbioru.

Innym przykładem braku zgody Niemcewicza na przestawianie i likwidowanie granic Rzeczypospolitej Obojga Narodów może być fragment jego relacji z przejazdu jeńców maciejowickich w grudniu 1794 roku do Petersburga, wśród których oczywiście on też się znajdował. Dotyczy ta notatka ziem białoruskich oderwanych od Polski po pierwszym rozbiorze: „W trzy dni drogi za Witebskiem wjechaliśmy w dawne granice moskiewskie, dotąd przebywaliśmy ciągiem prowincje Polakom wydarte" 25 .

Sztuczną pamiętnikarz nazywa granicę na Niemnie, aczkolwiek chyba sam jej uległ, skoro dodaje do swych uwag, że bardziej przyciągają go ziemie po lewej stronie rzeki:

Jechałem przyjemną drogą, po prawej ręce mając pięknym lasem okryte do wierzchołka, pasmem ciągnące się góry; po lewej Niemen, na drugiej stronie dzisiejsze Królestwo Polskie. Lubo obadwa brzegi od wieków i niedawno jeszcze jedno składały państwo, lubo mimo zaborów, odmiennych przezwisk, dla niewyrodnych Polaków wspólną zawsze składać będą ojczyznę, nie wiem, dlaczego serce moje bardziej ku lewemu skłaniało się brzegowi. Pochodziło to pewnie $\mathrm{z}$ tego imienia: brzeg polski ${ }^{26}$.

Wewnętrzne opory i abnegacje ożywiały się w Niemcewiczu szczególnie przy pokonywaniu stołecznych rogatek wyznaczających granice Warszawy. Wybudowano je jeszcze przed pierwszym rozbiorem i początkowo miały służyć za kordon sanitarny zabezpieczający mieszkańców przed epidemiami, zwłaszcza dżumą. $Z$ czasem ta funkcja rozszerzyła się i na rogatkach nadzorowano przepływ ludności. W okresie zaborów pełniły one ponadto funkcję urzędu celnego. Niemcewicz nie odnotowuje ich przekraczania aż do roku 1802, a więc do pierwszego powrotu z Ameryki. Potem kilkakrotnie wspomni o nich przy opuszczaniu i wjeżdżaniu do Warszawy, szczególnie zaś o rogatkach wolskich znajdujących się przy jedynej od strony zachodniej drodze do miasta,

Gdy tron przedał z rycerstwem Królestwa Polskiego,

Którego strata ciężki żal mi w sercu wznica,

Płakać każe nad sobą ojczyzny granica

Będąca w rękach cudzych. Kraju utracenie -

W Praterzburg jedne, drugie w Slonsko zamienienie,

A trzecie Niemcom daje, Galycjo nazywa" - Między rozpacza i nadzieją. Antologia poezji porozbiorowej lat 1793-1806, zebrał i oprac. M. Nalepa, Kraków 2006, s. 95.

25 J.U. Niemcewicz, Pamiętniki czasów moich..., t. 2, s. 132.

26 Juliana Ursyna Niemcewicza podróże..., s. 364.

Wrocławskie Studia Wschodnie 23, 2019

(C) for this edition by CNS 
a dokładnie przy zbiegu ulic Wolskiej, Towarowej, Okopowej i Chłodnej27. Dla oddania jego wrażeń z przekraczania tej granicy warto przytoczyć dwie jakże odmienne noty - jedną towarzyszącą wspomnianemu powrotowi ze Stanów Zjednoczonych w celu uporządkowania spraw majątkowych, a drugą sporządzoną, gdy pamiętnikarz wjeżdżał już do stolicy Księstwa Warszawskiego. Za każdym razem przeprawie towarzyszą inne uczucia - przygnębienia, gdy rogatek strzeże pruski żołnierz, i satysfakcji, gdy straż na nich trzymają wojskowi w polskich mundurach:

Jakże opiszę silne wrażenie, które na mnie sprawił wjazd do tej stolicy, w której w roku 1791 Polska odzyskała znaczenie i niepodległość, a która dziś z resztą całej Polski już była pod obcym panowaniem. U wolskich rogatek pruski żołnierz po niemiecku mię pytał. Miasto niegdyś tak huczne i ludne, dziś milczące i z rzadkim mieszkańcem. Nie bawiłem, jak 3 dni $^{28}$.

Przyjeżdżając do rogatek wolskich, miło mi było widzieć straż przy nich przez polskiego żołnierza trzymaną. Niestety! przez lat 11 trzymali ją Prusacy, niegdyś hołdownicy nasi. Było także w Warszawie kilka pułków francuskich, wszystko to pod dowództwem marszałka Davoust. Nie była to zupełna niepodległość, nie bez uciążliwościów, znośniejsza jednak od panowania drapieżców naszych ${ }^{29}$.

\section{Granice skorumpowane}

Podróżując do państw zachodnich, Niemcewicz spotkał się z nieuczciwością jedynie pograniczników francuskich, co tłumaczył rewolucyjnym nieokrzesaniem „gawiedzi”30. Ta wyjątkowość sprawiła, iż bardzo raziły go takie

27 To tutaj 2 listopada 1830 roku Fryderyk Chopin żegnał się na zawsze z Warszawą, a przyjaciele podarowali mu srebrny puchar z ziemią mazowiecką.

28 J.U. Niemcewicz, Pamiętniki czasów moich..., t. 2, s. 241.

29 Ibidem, t. 2, s. 267.

${ }^{30} \mathrm{~W}$ drodze do Ameryki zanotował: „Nazajutrz o 5-tej wjechaliśmy w bramy graniczne straszliwego imperium, z wruszeniem, które pamięć tylu nadzwyczajnych spraw tego ludu, okrucieństw, cnót i zwycięstw w umyśle moim sprawiła. Starsi przełożeni cła nie byli jeszcze przytomni; same tylko zastaliśmy gawiedź, niedawne ani nawet dzisiejsze, ale Robespierra czasy przypominającą. Jak kruki na pastwę, tak oni rzucili się na nasze małe kuferki, tłumoczki i szkatułkę, i pozabierali: szal, który wiozłem dla żony mojej, drugi, który od pani Krasińskiej wiozłem dla księżnej Aleksandrowej Sapieżyny, pudełeczko ze sznurkiem masy koralowej, łańcuszek pozłacany, parę kolczyków mozaikowych, nóż ogrodowy, dany mi od Stanisława Potockiego, w złoto oprawny (tego mi najbardziej żal), wiele kamyczków, drobiazgów, etc. etc. - Obrany tym sposobem, udałem się do dyrektora ceł p. Lamare i inspektora ceł p. Gaull; tych dwóch, osobliwie zaś podinspektora pana... znalazłem grzecznych i łatwych. Za przełożeniem mojem kazali mi wydać moje rzeczy, lecz znowu dwaj pierwsi łotrowie tyle przekładaniami swojemi zrobili, iż je kazali zatrzymać. Grzeczności tylko viceinspektora winienem, iż niektóre z drobnych kamyków mi powrócono. Na koniec po długiem chodzeniu, poceniu się i zmordowaniu aż do bolu w krzyżach, trzeba było porwanego łupu odstąpić. Znużenie fizyczne i rozum nie kazały się długo trapić tą przykrością i stratą, w sytuacyi mojej dość znaczną. Wróciłem do oberży la Wille de Paris. Zaledwom wsiadł, przesłano znowu, żeby iść do prefekta z po-

Wrocławskie Studia Wschodnie 23, 2019

(C) for this edition by CNS 
sytuacje na granicach poprowadzonych przez ziemie polskie. W ich opisie i ujawnianiu nie ma litości dla przypadków kradzieży, a szczególnie korupcji, zwykle piętrowej. W swoich uwagach na ten temat Niemcewicz jest złośliwy, ironiczny, impertynencki, a nie od dziś wiadomo, że celował on w twórczości satyrycznej, żartobliwej i paszkwilanckiej i zyskała mu ona wśród współczesnych Polaków wyjątkową popularność.

Jedną z „podróży historycznych” (na Wołyń i w Brzeskie) Niemcewicz rozpoczyna osobliwym opisem przekroczenia kordonu granicznego między Królestwem a Rosją. Warto zwrócić uwagę na to, że fragment ten w wydaniu z 1859 roku skrupulatnie wykropkowano.

Jeszczem się na drugą stronę do kordonu rosyjskiego nie przeniósł, gdy już celnik narodu tego przystąpił z powinszowaniem, iż wkrótce stanę w państwach N. Imperatora. Podług przyjętego w kraju tym zwyczaju, odpowiedź moja zawierała się w rublu. Gdym do drugiego przybił brzegu, znów drugi oficjalista doniósł, że mam się udać z paszportem na komorę; a z mojej strony znów drugi rubel. Szedłem więc pod górę, aż z boku trzeci wypada urzędnik i z troskliwym o całość ma przerażeniem ostrzega mię, że przed komora jest pies zły bardzo, rzucający się na podróżnych, i że on, dla obrony, towarzyszyć mi będzie; przyszliśmy na komorę, nie było psa: rubel trzeci. Na komorze wpisano w księgę paszport mój: rubel czwarty. Tu oświadczono mi, że z widzianym już paszportem przypuszczonym być mam do samego celnika. Ten, zatrzymawszy swój podpis, dał pozwolenie, że już i pojazd mój stanąć może przed jego oknami. Gdy się to stało, zapowiedział, że uroczysty obrządek rewizji może wkrótce nastąpić. Niemający i źdźbła, które by cłom lub zakazom podpadać mogło, odpowiedziałem, że gotów jestem. Widząc jednak, że się najwyższy urzędnik do obowiązku swego nie zabiera, poznałem co się to znaczy, położyłem na stole rubel piąty i szósty. Urzędnik wyszedł za drzwi, a ujrzawszy mały mój koczyk i mniejszy jeszcze tłumoczek, podpisał paszport i pożegnał. Tu nowa rzesza celników jęła mi winszować, żem tak szczęśliwie odbył rewizję: rubel siódmy. $\mathrm{Z}$ tego wszystkiego ta moralna wypadła nauka i że ja rubli siedm miałem mniej w kieszeni. Skarb N. Imperatora i jedną kopiejką zbogaconym nie został; sami tylko wierni i przykładni urzędnicy jego zyskali. Z tym wszystkim, gdy cło, gdy ta największa podróżnych plaga, zdaje się rządzącym rzeczą tak słodką, tak nieodbicie potrzebną, wolę ten już pewny pozbycia się wszystkich mitręg sposób niż nieznośne celników w innym kraju męczenia ${ }^{31}$.

Pamiętnikarz wielokrotnie przypomina, że nigdy nie przejechał granicy rosyjskiej bez problemów ${ }^{32}$, co w końcu uznał za normalne zjawisko, choć

kazaniem paszportu. Jean Bon de St. André, znany nie bardzo dobrze w pierwszych latach rewolucyi, odesłał nas do swego sekretarza. Ten opisawszy twarze, oczy, nosy, włosy, wzrost etc., za godzinę kazał przysłać po paszporty. W ciągu dnia żandarmowie trzy razy przychodzili przypatrywać się naszym paszportom, czyli to przez próżną ciekawość, czyli na koniec z nałogu, który lud ten w czasie rewolucyi nabył wystawianiem najwyższej władzy od rana do wieczora" - Pamiętniki Juliana Ursyna Niemcewicza 1804-1807. Dziennik drugiej podróży do Ameryki, Lwów 1873, s. 42-43.

31 Juliana Ursyna Niemcewicza podróże..., s. 169-170.

32 Przeprawę w strony rodzinne w 1802 roku opisał w następujący sposób: „Przebywszy granicę nie bez zwykłych w Moskwie na komorze przekor, zajechałem do Adamkowa" J.U. Niemcewicz, Pamiętniki czasów moich..., t. 2, s. 242. Bez większych problemów natomiast przekraczał granicę pruską, co odnotował przede wszystkim w Podróżach historycznych.

Wrocławskie Studia Wschodnie 23, 2019

(C) for this edition by CNS 
przecież zdarzały mu się niemiłe sytuacje także na granicy prusko-austriackiej. Dał na przykład barwny opis przekroczenia kordonu w widłach Wisły i Sanu, gdy w 1820 roku wjeżdżał na tereny Galicji. Okazało się wówczas, iż nie może bezpośrednio przedostać się na drugą stronę z Kongresówki, lecz z Prus, i że strzegący granic celnicy są szczególnie uwrażliwieni na przemyt niebezpiecznych politycznie książek i tabaki. Czynili przy tym zakusy skonfiskowania poecie srebrnej łyżeczki:

Przystępy najniegodziwsze, jakby umyślnie dla psucia pojazdów robione. Obrządki celne na drugiej stronie dość długo trwały. Przetrząsano wszystko, szukając ksiąg i tabaki. Przykra to jest niezmiernie rzeczą, chudobę swoją przed cudzymi ludźmi rozpościerać. Znaleziono łyżkę srebrną, chciano ją ponderawać; jednak celnik, wspaniałością ruszony, przepuścił ją wolną ${ }^{33}$.

\section{Podróże historyczne}

Przedsięwzięcie realizowane przez Niemcewicza od 1811 do 1828 roku dawało mu możliwość wielokrotnego przekraczania granic, którymi państwa zaborcze pokawałkowały Polskę. Najważniejszą ich motywacją było sprostanie podróżniczym i patriotycznym wyrzutom sumienia. Niemcewicz nie czuł się bowiem dobrze z myślą, że przewędrował trzy kontynenty, a nie dość dobrze poznał własny kraj. Druga przyczyna miała podłoże bardziej duchowe, czy też ideowe. Jak wcześniej powiedziano, autor Śpiewów historycznych kontestował rozbiory i nowo poprowadzone granice. Chciał zatem ukonkretnić ten sposób myślenia o Polsce, w związku z czym jego opisom towarzyszy wyraźny duch konfrontacji i porównania. Są to przede wszystkim zestawienia historyczne biorące pod uwagę czasy przedrozbiorowe i czasy ujarzmionego narodu. Z góry trzeba jednak zaznaczyć, że nie zawsze prosto przekładają się one na binarne układy, typu: świetność-upadek, gospodarność-nędza, wolność-niewola. Choć ten schemat dominuje, to jednak w podróżach historycznych znajdziemy niewiele tonów macphersonowskich czy volneyowskich. Niemcewicz nie czuł się dobrze wśród grobów albo ruin, nie kosztował ich tak jak Gajusz Mariusz czy Vitalis, czy nawet odrzykoński wariat Jan Machnicki. Trafnie charakter tych podróży i ich efekt w formie pamiętnika scharakteryzował Adam Jerzy Czartoryski:

Manuskrypt jego Historycznych po kraju podróży, złożony do wydania w drukarni puławskiej w końcu 1830 i szczęśliwie ocalony, dopiero w 1857 w Paryżu drukiem ogłoszony został. Dziennik tych podróży jest pisany z właściwą Niemcewiczowi łatwością, szczerością i rozmaitością stylu, co ten rodzaj pism przyjemnym czynią. Niemcewicz starał się wszystkie strony dawnej Polski, od Królewca do Odessy, objechać. W dzienniku jego podróży pełno jest faktów, wydarzeń, opisów i postrzeżeń ważnych nad stanem wszystkich części kraju (gdyż

33 Juliana Ursyna Niemcewicza podróże..., s. 423.

Wrocławskie Studia Wschodnie 23, 2019

(C) for this edition by $\mathrm{CNS}$ 
żadnej nie opuścił), w czasie, gdy je zwiedzał. Myśl piękna, użyteczna, obywatelska, dowodząca, że autor w opisach przeszłości zawsze myślał o przyszłości kraju, i że w każdym prawie rodzaju uprzedzał przedsięwzięcia, które po nim teraz przez gorliwych i utalentowanych ludzi dopełniają $\operatorname{się}^{34}$.

Drugą orientacją porównawczą w podróżach Niemcewicza z lat 1811-1828, zwłaszcza na wschód „bywszej Rzeczypospolitej”, były zapewne jego własne obserwacje i przeżycia z młodzieńczych — zagranicznych ${ }^{35}$ i krajowych — peregrynacji, szczególnie na Kresy, zwiedzane już w latach osiemdziesiątych XVIII wieku. Znów celne spostrzeżenia w tym względzie odnotował Adam Jerzy Czartoryski:

Porównywając co czuł i co widział w młodości swojej i w podeszłym potem wieku, jakże musiał rozmyślać nad smutną różnością położeń, stosunków, obrazów kraju i ludzi w tych dwóch porach swego życia; jakże i sam zmieniony i wszystko tam znalazł zmienione! ${ }^{36}$

Pierwszą z tych wędrówek historycznych Niemcewicz odbył w 1811 roku w Krakowskie, Sandomierskie i Lubelskie, drugą rok później do Prus Książęcych, w 1816 roku wyprawił się na Wołyń; po Prusach Polskich i ponownie Książęcych wędrował w 1817 roku, następnie udał się na Wołyń i Podole aż po Morze Czarne (1818), na Litwę (1819), Ruś Czerwoną i Podkarpacie (1820),

34 Żywot J.U. Niemcewicza..., s. 192. Zob. M. Chachaj, Pamięć i zapomnienie - uwagi na marginesie „Podróży historycznych po ziemiach polskich między rokiem 1811 a 1828 odbytych” Juliana Ursyna Niemcewicza, [w:] Tożsamość. Kultura. Nowoczesność, t. 2. Czas. pamięć, red. B. Morzyńska-Wrzosek, M. Kurkiewicz, I. Szczukowski, Bydgoszcz 2017, s. 51-62.

35 Po podróży na Litwę w 1819 roku Niemcewicz wyciągnął następujące wnioski: ,Skończywszy tę podróż po znaczniejszej części Litwy, cóż mam o ogólnym stanie, i kraju, i mieszkańców, powiedzieć? Ach, jakże dalekim jest od tego bytu, w którym by go i życzenia nasze widzieć pragnęły i położenie jego pod lepszym zarządzeniem postawić mogło. Jakiemikolwiek przedmiotami uderzonym jest człowiek, sądząc o nich, porównywa je z innymi. Ileż traciła biedna Litwa moja, gdym ją w umyśle moim równał z innymi w Europie krajami! Pytałem siebie, czyliż grunta, czyliż rodzajność Brandeburgii, wielu części Saksonii, Szampanii we Francyi, skalistej Szkocyi i Szwecyi, lepsze są od ziemi naszej na Żmudzi, w Kowieńskiem, Nowogródzkiem, Wołkowyskim itd.? Łatwa odpowiedź: iż Litwa nasza żyźniejszą jest w płody ziemskie od wszystkich tych pomienionych krain. Czemuż, zapytałem znowu, w ubogich nawet prowincjach Francyi, Szkocyi, Szwecyi, w piaszczystej Brandeburgii, widzimy lud swobodny, porządne miasteczka, uprawne role i wysilony przemysł człowieka, nagrodzony dobrym bytem? Małe, otoczone burzliwym oceanem na wyspach Orkadach miasteczko, nierównie jest bardziej i kwitnącym i zamożnym, jak panujące nad wielu rzekami Kowno lub Pińsk. Odpowiedź na to wszystko jest równie łatwa, jak niebezpieczna. Mówią, że człowiek, to duchem i światłem niebieskim obdarzone jestestwo, wszystkie swoje zdolności do wydoskonalenia siebie i bytu swego obracać powinien; mówią, że te nabycia, pokolenia pokoleniom w dziedzictwie oddawać powinny. Jam w zabranych prowincjach widział przeciwnie. W nich, nie wydoskonalenie zdolności umysłów, lecz coraz większe zepsucie i nędzę pokolenia podają sobie" - Juliana Ursyna Niemcewicza podróże..., s. 414.

36 Żywot J.U. Niemcewicza..., s. 25.

Wrocławskie Studia Wschodnie 23, 2019

(C) for this edition by CNS 
do Wielkopolski i na Śląsk (1821), w końcu na Podlasie (1828). Okazje do podjęcia podróży były różne: wolny czas, zaproszenia, misje oświatowe, interesy majątkowe i sprawy rodzinne (przykładowo ostatnią wyprawę, na Polesie, przedsięwziął z uwagi na wesele bratanka Tadeusza).

\section{Granice: Prusacy i Żydzi}

W Podróżach Niemcewicz powtarza w zasadzie to wszystko, co wyraził wcześniej w pamiętnikach. Podkreśla przede wszystkim, iż przez granicę pruską można swobodnie przejechać, bez uciążliwych kontroli i nieprzyjemności celnych:

W deszcz i zimno wybrałem się w dalsza [dalszą?] drogę z Wrocławia, niedoznawszy przy bramach żadnej rewizyi, żadnego nawet zapytania. Jak z wielu innych względów, tak i z tego oddać trzeba sprawiedliwość rządowi pruskiemu, iż nie jest ani dręczącym niepotrzebnie, ani podejrzliwym, i że człowiek i myśl jego rozsądnej doznają wolności ${ }^{37}$.

Już sama ciekawość zwiedzenia miejsc starożytnych, popchnęła mię dalej aż do Inowrocławia, stolicy niegdyś województwa tegoż imienia, dziś już za kordonem pruskim. Puszczono mię przez granicę bez żadnych mitręg doznawanych gdzieindziej ${ }^{38}$.

Równocześnie jednak jest zaniepokojony owym pozornym liberalizmem, z którego korzystają niegdysiejsi mieszkańcy Rzeczypospolitej, bo z jednej strony cenią sobie względną swobodę obywatelską — tym samym przekraczając granice, nie odczuwają wolnościowych uniesień ducha. Z drugiej zaś niebezpiecznie wtapiają się oni w germański etnos, w którym pożądane cechy — porządek, czystość, wygoda — są tak naprawdę skutkami wymuszonej przynależności państwowej ${ }^{39}$. Zwraca też uwagę na specyfikę granic pruskich, które były wytyczone, jeszcze gdy Polska częściowo istniała, i na tej samej linii demarkacyjnej zachowały się po trzecim akcie rozbiorowym. Po wsiach przygranicznych pod obu stronach słyszy się więc polską mowę; obyczaje i obrzędy

37 Juliana Ursyna Niemcewicza podróże..., s. 500.

38 Ibidem, s. 241.

39 Niemcewicz tak opisuje etniczną i demograficzną strukturę mieszkańców Wrocławia: „W niedzielę byłem na mszy w kościele Ś. Krzyża i na wybornym polskim kazaniu, co do języka prawdziwie staroświeckiej wymowy i treści. W innych katolickich kościołach kazano po niemiecku; kanonik Kruger słynie tu z kościelnej wymowy. Wrocław, równie jak cała część Szlązka po lewej stronie Odry, zniemczał od dawna. Początkiem zniemczenia tego było wpadnięcie Tatarów do Szlązka w r. 1226 i wycięcie w nim dawnych polskich mieszkańców. Panujący książęta, by spustoszony kraj zaludnić, sprowadzać musieli, z oszczędzonych przez miecz pogański Niemiec, znaczne kupy osadników. Ci krzewiąc się prędko, wkrótce sławiańską krainę przemienili w niemiecką. W kościołach katolickich nie widziałem jak żołnierzy i uboższą klasę ludu; majętniejsi są Lutra wyznania; rząd z trudnością katolików na urzędy wynosi" - ibidem, s. 499.

Wrocławskie Studia Wschodnie 23, 2019

(C) for this edition by CNS 
niczym się nie różnią, dominuje wiara katolicka ${ }^{40}$. W żadnym jednak momencie swojej relacji Niemcewicz nie odżegnuje się od myśli o tym, że Prusacy podobnie jak inni zaborcy — „Zgwałcili granice Rzeczypospolitej”. Nie stara się także, choćby częściowo, wyjaśniać przetrwania wspólnoty transgranicznej łagodnością króla pruskiego i jego urzędników. Ową wspólnotę, w jego przekonaniu, mają bowiem pielęgnować polskie kobiety — babki i matki — niezależnie od nacisków politycznych czy ideologicznych.

Mały strumyk, Zimne Wody zwany, od niepamiętnych wieków dzielił Polskę od Szlązka. Póki dobra wiara mieszkała na ziemi, dosyć było strumienia tego. Później, najpotężniejsze twierdze, przeciw pysze i chciwości, dostateczną nie były warownia. Gdyby nie mały przykomorek, pięć utkwionych w ziemię dzid i kilku kozaków, którym paszport mój do podpisania dawać musiałem, nie byłbym wiedział, że to granica. Wszystko na drugiej stronie, wszystko takie jak u nas; taż sama mowa, strój, obyczaje, położenie kraju, wszystko świadczy że Polska i Szlązk jednym narodem, jedną były kraina. Mimo przez tyle wieków ciągłych usiłowań Niemców, została mowa Polska szczególnie w pospólstwie taką, jaka była za Piastów. I któż ją utrzymał? Nie szlachta zapewne, tak łatwo przekształcająca się k’woli rozkazów i wzorów tych, od których łaski spływają; nie niższa nawet płeć męska, wędrująca, służąca w wojsku, ucząca się rzemiosł u obcych: utrzymała ją płeć żeńska, przeznaczona żyć na tych zagrodach domowych, na których pradziadowie ich żyli, chwaląca Boga w tych modlitwach, w tych pieniach, w których go oni od tylu wieków chwalili, w tym języku kołysząca niemowlęta swoje, w tej mowie udzielająca im pieszczot i tkliwych serca macierzyńskiego uczuć. Tak jest, narody poniżone, zawojowane, winny są jedynie

40 Zwrócił na to też uwagę Kazimierz Brodziński we fragmentach Dziennika wojskowy z 1813 roku; zob. M. Nalepa, Rok 1812 we wspomnieniach Kazimierza Brodzińskiego, [w:] idem, Porozbiorowe migracje w literaturze późnego oświecenia. Studia nad wybranymi tekstami, Rzeszów 2018, s. 157-185. W tym samym roku również Niemcewicz, tak jak twórca Wiesława, zmierzał do Drezna. Z perspektywy ośmiu lat czasu skomentował tę wędrówkę niezwykle dramatycznym opisem, przypominającym wspomnienia i Brodzińskiego, i Fredry: „Dopełniając ciągu przedsięwziętych od lat tylu podróży moich historycznych po Polsce i po należących niegdyś do niej prowincjach, umyśliłem roku tego odwiedzić Wielkopolskę i Szląsk. Widziałem już wprawdzie krainy te, lecz tylko spiesznym przejazdem i w jakimże czasie? Oto w początku pamiętnej srogością swą zimy 1813 roku. Niestety, co za odmiana! Dziś odmłodniało przyrodzenie całe; łagodne niebo, wszędzie świeża majowa zieloność i rozlegające się pieniem ptasząt powietrze. Wtenczas w mróz dwudziestopięciostopniowy, uchodziłem wraz z tłumem z całej Europy zebranych przed miesiącem zwycięskich, dziś rozproszonych hufców. Gospody wszystkie napełnione były konającymi; ogień, zamiast ogrzania zdrętwiałych członków, w prędkim zgonie w oczach moich koniec ich mękom przyspieszał. Po gościńcach rozciągnięte te trupy, w mundurach różnych narodów; nabita jeszcze broń leżała obok nich; nic pokryła mieszkańców Tagu i Sekwany ziemia ich ojczysta, lecz iskrzące się obce nieba oświecały okropność ostatniego ich kresu. Wielki Boże, jak straszne są skutki błędów tych, co ludźmi władają! Rozkażą w dumnym zawrocie swoim, i na rozkaz ich tysiączne pokolenia okropną śmiercią ginąć muszą. Dziękujmy Bogu, że się te okropności skończyły, błagajmy go, by natchnął panów świata duchem umiarkowania, uleczył ich od żądzy rozkazywania obcym, przywłaszczania tego, co nie należy do nich. Niech straszny przykład Napoleona nie stawa się próżnym" - Juliana Ursyna Niemcewicza podróże..., s. 465.

Wrocławskie Studia Wschodnie 23, 2019

(C) for this edition by CNS 
kobietom, że z niepodległością swoją nie straciły i tej jedynej różniącej naród od narodu cechy, to jest mowy ojczystej. Zachował ją lud szląski zupełnie, przynajmniej po prawym brzegu Odry ${ }^{41}$.

Podkreśla równocześnie, że Prusacy mają szczególne umiejętności w asymilowaniu obcych narodów, nawet tych, którym religia nie pozwala na przyjmowanie cudzych obrzędów i obyczajów. Czyżby widział w tym również zagrożenie dla podbitych Polaków? Znów, w opinii Niemcewicza owe zmiany adaptacyjne dotyczą przede wszystkim granic, na których w stosunkowo krótkim czasie wykształciło się w miastach i miasteczkach swoiste pogranicze prusko-żydowskie.

Jak w innych miastach, tak i w Inowrocławiu, Żydzi pierwsze miejsce trzymają. Uczynili przecie w kordonie pruskim, czego w Polsce uczynić nie chcą: przebrali się po niemiecku. Wątpię, by charakter, prawidła swoje, by Talmud porzucili wraz z suknią. Połamali jednak niewygodne sobie przepisy: nie zachowują szabasu, koszernego; słyszałem ich nawet mówiących o kuglu, o cycele z nieuszanowaniem, które mię, acz chrześcianina, zgorszyło ${ }^{42}$.

Niemcewicz ten stan rzeczy objaśnia z jednej strony wyrachowaną polityką pruską, z drugiej — koniunkturalizmem i nieuczciwością Żydów. Dlatego też, pomimo pozornej łagodności celników i pograniczników „rakuskich”, emocjonalnie reaguje na granice z Prusami, przypominając o północnym hołdowniku Rzeczypospolitej i jej kurateli wobec sąsiadów, którzy na koniec okazali się „krwawożerczymi drapieżnikami”:

O półtory mili stamtąd, orzeł pruski czarny, noszący w brzuchu swoim małego orła białego, oznacza granice niegdyś Królestwa Polskiego, dziś Księstwa Poznańskiego. Pograniczne nasze miasta od Szląska, jako to: Rawicz, Wschowa, Bojanów, Rydzyna i Leszno, przed dwoma blisko wiekami osadzone były kolonistami niemieckimi, lutrami, przed prześladowaniami religijnymi chroniącymi się na ziemię tolerancji i wolności ${ }^{43}$.

Na granicy od strony rosyjskiej tę emocjonalność Niemcewicza wzmacniają kradzieże, korupcja, złe traktowanie podróżujących i pogranicznych mieszkańców. Pod tym względem tak wygląda konfrontacja obydwu stron kordonu — pruskiej i rosyjskiej:

W Warężu przeprawiłem się przez komorę rakuską, a o milę przez naszą. Tu zastałem nie tylko naszych celników, lecz i moskiewskich. Ci ostatni, od ustanowienia tu swego, nie odbyli i jednej ekspedycyi. Lecz piętnastu Kozaków, dla strzeżenia nas rozstawionych, codziennie w ich zastępstwie przedsiębiorą wyprawy: to na miejscu, po chłopskich i pańskich stodołach, gumnach, łąkach i polach; to za granicą, gdzie przeszłej właśnie nocy, zabrali pięć wołów i jednego wieprza karmnego. Nieraz, gdy ładowna bryka kupiecka już się na komorze naszej odprawi i pół mili odjedzie, lecą Kozacy za nią, zwracają nazad, pod pozorem że to nie kupiec, lecz jedzie przebrany oficer. Jakże ma nieszczęsny furman lub kupiec z takim ciężarem powracać nazad i tracić tyle drogiego czasu? Więc w targi, trzeba znowu zapłacić kilka rubli, i dopiero wtenczas oficer staje się prawdziwym furmanem i jedzie dalej ${ }^{44}$.

41 Ibidem, s. 485.

42 Ibidem, s. 241.

43 Ibidem, s. 500.

Wrodbifawskie 458 dia Wschodnie 23, 2019

(C) for this edition by CNS 


\section{Kresy, pogranicza stykowe}

Granice i pogranicza były dla Niemcewicza miejscami wrażliwym, gdyż uważał, że stwarzają nową rzeczywistość porozbiorową, która z czasem przeniesie się na inne tereny ( $\mathrm{w}$ głąb), szczególnie w zaborze rosyjskim. Tymi niepokojącymi zjawiskami są korupcja, nieuczciwość, brak życzliwości i zrozumienia oraz przejęcie miasteczek przez żywioł żydowski. Zdaniem pamiętnikarza oprócz drapieżnych sąsiadów najwięcej na rozbiorach zyskali właśnie Żydzi, a miarą tego sukcesu jest ich przeniesienie się ze wsi i z peryferii do centrów urbanistycznych oraz korzyści wynikające $\mathrm{z}$ handlu przygranicznego. Jednakże tereny transgraniczne wykształciły się na liniach demarkacyjnych wytyczonych w sposób bezprawny, zagrażają więc wspólnocie etnicznej Polaków i z tego względu Niemcewicz nie poczytuje ich, jak czynią to współcześni socjologowie i antropolodzy, za obszary multikulturowe oparte na dialogu i wymianie wartości ${ }^{45}$. Przykładem niech będą zauważone przez pisarza skutki poprowadzenia granicy wzdłuż Niemna. Mieszkańcy obu brzegów „rzeki domowej” stali się względem siebie nieufni czy nawet wrodzy, a dodatkowo ów podział graniczny między nimi wzmacniają wały wojskowe:

Brzegi Niemna są niskie, równające się prawie z powierzchnią wody. Lubo mieszkańcy dwóch brzegów pod jednym dziś żyją berłem, i tak są blisko siebie, iż mówić z sobą mogą, przecież jakby były nieprzyjacielskie, jakby w czasie wojny, niepotrzebną ostrożnością przerwanym jest wszelkie między nimi spotkanie. Na brzegu Polski widać wysypane szańce, w wojnach ostatnich i dawnych ${ }^{46}$.

Funkcja kształtowanych przez stulecia granic państwowych Rzeczypospolitej polegała na oddzielaniu sąsiadujących z sobą społeczności, zróżnicowanych najczęściej pod względem językowym, religijnym i narodowościowym (etnicznym $)^{47}$. W wypadku agresji politycznej dokonanej przez zaborców

45 Por. np. G. Babiński, Pogranicze polsko-ukraińskie. Etniczność, zróżnicowanie religijne, tożsamość, Kraków 1997; Kultura pogranicza - pogranicze kultur, red. A. Bobryk, Siedlce-Pułtusk 2005; Kultury regionalne i pogranicza kulturowe a świadomość etniczna. Studia etnologiczne $i$ antropologiczne, red. I. Bukowska-Floreńska, t. 2, Katowice 1999; W. Panas, O pograniczu etnicznym $w$ badaniach literackich, [w:] Wiedza o literaturze $i$ edukacja, red. T. Michałowska, Z. Goliński, Z. Jarosiński, Warszawa 1996; Pogranicze jako problem kultury, red. T. Smolińska, Opole 1994; G. Ritz, Kresy polskie w perspektywie postkolonialnej, [w:] (Nie)obecność. Pominięcia i przemilczenia w narracjach XX wieku, red. H. Gosk, B. Karwowska, Warszawa 2008; A. Stępnik, Pogranicze jako przestrzeń badawcza, [w:] Galicja 17721918. Problemy metodologiczne. Stan i potrzeby badań, red. A. Kawalec, W. Wierzbieniec, L. Zaszkilniak, t. 1, Rzeszów 2011; Tożsamość terytorialna $w$ różnych skalach przestrzennych, red. Z. Ryk1, Rzeszów 2010; S. Uliasz, Literatura Kresów - kresy literatury, Rzeszów 1994.

46 Juliana Ursyna Niemcewicza podróże..., s. 364.

47 Ta funkcja granicy, zdaniem Niemcewicza, najlepiej sprawdziła się przy oddzielaniu Królestwa Polskiego od Dzikich Pól: „Kraj, przez który przejeżdżałem, wstępem do stepów nazwać by można. Już bardzo rzadkie osady, rzadka dla szczupłości rąk uprawa. Trawa, po

Wrocławskie Studia Wschodnie 23, 2019

(C) for this edition by CNS 
odgrywają jednak diametralnie inną rolę — rozbijają historycznie ukształtowaną wspólnotę narodową. Nie ma więc mowy o czymś takim jak „korzystanie i przyswajanie dwóch lub więcej kultur i w efekcie kształtowaniu dwoistego systemu tożsamości"48 na terenach uformowanych wokół sztucznych i podstępnie przeprowadzonych granic. Wyznaczono je w dodatku w miejscach przypadkowych, co spowodowało bardzo głębokie zmiany w życiu okolicznych mieszkańców, kompletnie zrywające wielowiekową ciągłość kulturową tych terenów. Co więcej, Polacy zostali wyparci z przygranicznych miejscowości i zasiedlili je zaborcy albo zamieniono je w żydowskie sztetle. Takim są dla Niemcewicza Brody, wcielone po pierwszym rozbiorze do imperium Habsburgów - patrzy na toczące się w nich życie z obrzydzeniem i niepokojem:

Powaga gospodarza domu i pomoc czeladzi, ledwie zdołały oddalić ode mnie te brudne łapserdaków zastępy. Chciałem wytchną́ cokolwiek; lecz ustawicznie, pomimo straży, to przez drzwi, to nawet oknami, wdzierało się żydowstwo $\mathrm{z}$ towarami pod pachą. Lubo zmęczony drogą, by się natręctwa uchronić, wyszedłem na miasto. Oprócz dwóch ulic, i tam i ówdzie rozrzuconych murowanych domów, całe miasto jest drewniane, całe niebrukowane, całe brudne, gdzieniegdzie tylko mające po bokach pomosty z dylów. Wszedłem na rynek: jest to ogromny czworogran we środku starą budowę ze sklepami mający. Przebóg, jakież widowisko uderzyło oczy moje! Ośm lub więcej tysięcy Żydów w lisich czapkach lub czarnych kapeluszach, ściśle skupionych na namowy i szachry rozmaitego rodzaju, pod nogami błoto, po bokach obryzgane błotem ściany, niebios nawet sklepienie czarną i dżdżystą powleczone oponą; gęste i ciężkie powietrze przez odrażające wyziewy cebuli i czosnku... mniemałem się być w samym przysionku obrzydliwego piekła. Na widok ten ciężkim obarczony smutkiem, takie, pomyślałem sobie, będą wszystkie miasta nasze, taka będzie Warszawa, co mówię, taka z wiekami będzie i cała Polska nasza! Nikt się nie zdziwi zapewne obrazowi temu, gdy mu powiem, że w rozwlekłym mieścisku Brodach, podług lustracyi która zapewne niżej jest prawdy, liczą 24000 Żydów, chrześcijan zaś 3000 tylko. Mniej i to zadziwiać będzie, że gdy jeden tylko na całe miasto jest katolicki kościół, żydowskich synagog liczy się dwie ogromnych katedralnych, sześć średnich i dwadzieścia mniejszych bożnic. Od tych wszystkich niezmierne opłaty idą do rządu. Dwa były niegdyś możne handlowe domy chrześcijańskie w Brodach: Laszkiewiczów i Mullera. Iwaszkiewicz, sprzykrzywszy sobie przekory Żydów, zamknął swój handel, Muller zbankrutował. Dziś dom handlowy Hausnera jedną jest tylko maleńką wysepką chrześcijańską wynurzającą się z pośród niezmierzonego okiem oceanu Żydów ${ }^{49}$.

łąkach po pas prawie wysoka; częste i dość wyniosłe góry. W przeciągu dziesięciu mil polskich, ledwie trzy wiosek postrzegłem, znaczniejsze między niemi Czernecze i Kozackie. O południu przyjechałem do Bałty. Tu była granica niegdyś Królestwa Polskiego ze strony krymskich Tatarów; rzeczka nazwana Bałtką, podług drugich Kodymą, idąca od Bałty do Bohu, dzieliła dwa kraje. Mało już śladów Polski jest w Bałcie. Ludność, prócz Żydów, cała prawie jest rossyjska; podobnież i zwyczaje; orientalność przebijać się zaczyna. Otwarte pod wystawami sklepy; brodacze na ulicach pod gołem niebem szynkujący czaj pospólstwu. Bałta zdaje się dosyć zamożnem i ludnem miastem. Tu ultima Thule: dalej, aż do Czarnego Morza, niegdyś dzicz tatarska, aż dotąd po mapach Dzikiem Polem zwana" — ibidem, s. 308.

48 J. Nikitorowicz, Pogranicze, tożsamość, edukacja międzykulturowa, Białystok 2001, s. $12-13$.

49 Juliana Ursyna Niemcewicza podróże..., s. 455-456.

Wrocławskie Studia Wschodnie 23, 2019

(C) for this edition by CNS 
Niemcewicz w swoich relacjach z podróży, zwłaszcza po Kresach, z jednej strony kontestuje granice rosyjskie i austriackie, $z$ drugiej jednak tworząc (jedynie w wyobraźni i pamięci) własne - etniczne, wyraźnie stykowe, różnicujące, mocno emocjonalne, dotyczące trzech stereotypowo postrzeganych narodów: nieoświeconych Rosjan, podstępnych Żydów i skrzywdzonych Polaków. Przewagę na granicach, poprowadzonych centralnymi niegdyś terenami Rzeczypospolitej, uzyskują oczywiście dwa pierwsze. Są one winne zniszczenia homogenicznej struktury narodowościowej i zachwiania zbiorowej identyfikacji Polaków. Żydzi w ocenie Niemcewicza uczynili z Brodów centrum sieci handlowej rozciągniętej na dwa kontynenty:

Doczekałem się na koniec gubernatora Giżyckiego. Opatrzony przez niego podorożną, puściłem się w drogę. O milę za Krzemieńcem spotkałem sto dwadzieścia maż z kufami łoju, ciągnionych przez woły; dążyły do Radziwiłłowa, celnej tutejszej komory, skąd przez Brody rozejdą się w dalekie może strony Europy. Ludzie ci, spaleni słońcem i wyschli, już pięć niedziel jak wyruszyli z Odessy. Tłusty Niemiec lub lekko żywy Francuz, zapalając lampę na urodziny lub imieniny książątka swego, dekorator oświecający scenę Armidy lub Galatei, mało pomyślą, że topiący się w ich lampach łój, przyszedł z nadbrzeża Dniepru lub Wołgi. Takie są dobroczynne skutki handlu. Wzajemną zamianą, mieszkańcy rozmaitych stref świata, używają wszystkich płodów onego. Francuz odziewa się skórą Kamczatki, a rządca Tobolska chodzi w sukni angielskiej i pije wino Burgundyi. O, jakżeby dobrodziejstwa te obficiej jeszcze zlewały się na narody, gdyby rządy, potrzebom przemysłu licznych i ciężkich nie stawiały zapór. Tamożnie czyli komory są tak, jak owe dnieprskie porohy, jak owe po brzegach morskich skały, o które rozbijają się wszelkie ludzkiego przemysłu usiłowania ${ }^{50}$.

Ów ogląd granic porozbiorowych, zwłaszcza wschodnich, przez Niemcewicza był konsekwentnie podtrzymywany także w stosunku do opinii głoszonych przez niego przed 1795 rokiem. Podstawą były tu różnorakie doświadczenia i przeświadczenia, od aktywności kadeckiej począwszy, przez związki ze środowiskiem puławskim, podróże zagraniczne, udział w życiu publicznym, a na represjach politycznych skończywszy. Tę specyfikę Niemcewiczowską można wyłuskać, porównując jego zapisy z relacjami innych pamiętnikarzy. Na przykład 18 kwietnia 1820 roku punkt graniczny między Radziwiłłowem a Brodami, tak barwnie przedstawiony przez autora Podróży historycznych, przekraczał jezuita Jan Galicz. W jego sprawozdaniu niepokój o przyszłość ojczyzny wyraźnie przesłania troska o losy Societatis Iesu, którego członków Aleksander I dekretem z 13 marca 1820 roku usuwał z imperium carów. Ponad dwustu zakonników w krótkim czasie musiało w związku z tym opuścić Rosję, a jednym z nich był rzeczony Galicz. W jego pamiętniku nie odnajdujemy skarg, napięć, żywiołowych tonów związanych z przekroczeniem granicy. Ani on, ani jego towarzysze nie mają żadnych problemów wyjazdowych; być może ze względu na sutannę i sytuację wygnania pogranicznicy rosyjscy i austriaccy traktują ich wyjątkowo uprzejmie. Sytuacja na styku zaborów nie wzbudza

50 Ibidem, s. 296-297.

Wrocławskie Studia Wschodnie 23, 2019

(C) for this edition by CNS 
w Galiczu zainteresowania; zaprzątnięty jest jedynie myślą o sprawnej oraz nieuciążliwej dla siebie i współbraci podróży. W jego pamiętnikach pojawia się wprawdzie nostalgiczna nuta „pożegnania ojczyzny”, ale raczej Białorusi, w której Katarzyna II na kilkadziesiąt lat po breve kasacyjnym Klemensa XIV pozwoliła synom Loyoli schronić się i działać bez przeszkód. Tym razem to austriackie komory graniczne stanęły otworem przed jezuitami, gdyż cesarz Franciszek I chciał im powierzyć parafie i organizację szkolnictwa w Galicji. Pamiętnikarz zamyka pierwszą część swoich wspomnień następującym opisem:

Dnia 18 kwietnia przybyliśmy szczęśliwie do Radziwiłłowa. Zająwszy nam kwaterę, wstąpiliśmy do parafialnego kościółka na niedzielne nabożeństwo, po którym kanonik a zarazem proboszcz miejscowy zaprosił nas na przekąskę. Po obiedzie odwiedził nas horodniczy miasteczka i zapewnił naszą przeprawę przez pograniczną komorę. O godzinie piątej odbyliśmy zwyczajne ceremonie przy komorze rosyjskiej. Toż według zwyczaju w towarzystwie dwóch Kozaków z chorągiewkami na koniach przybyliśmy do komory przygranicznej austriackiej o wiorstę od rosyjskiej odleglej [odległej?]. Tam tylko podpisali nasze paszporty, a inne ceremonie później odbyliśmy w mieście Brody (o czem w drugiej części). Kiedym poznosił podpisane paszporty, pewny jenerał Polak, nie wiem, z jakim zamiarem, a wesoła jednak twarzą, zawołał: „Mości Księże! A cóż to! W tak daleką podróż? Z Panem Jezusem i paszportem?” Na tom tak odpowiedział: „Dosyć dla nas, resztę wszystko chętnie Moskalom zostawujemy”. Wtem przejeżdżamy rogatkę rozgraniczającą Austrię od Rosji i naszą lubą Ojczyznę żegnamy:

\section{Żegnam Cię, Ojczyzno miła! \\ Jużem na obcej ziemi. \\ Obyś się mi znów wróciła \\ Z towarzyszy mymi! \\ W dalekiej, obcej krainie \\ Ty będziesz mi w pamięci; \\ Tam imię twe zasłynie \\ I czyn, co wdzięczność święci. [...]}

W takowych lub tym podobnych myślach czyniąc znak krzyża św. przejeżdżaliśmy granicę, nie bez trudu i przykrości. Miasto Brody od Radziwiłłowa odległe o 5 lub 6 wiorst, droga piaszczysta, poczta niedogodna, deszcz rzęsisty zapóźniały nieco nasz przejazd na czas. Żydowie niezgrabni radziwiłłowscy pocztylionowie uchodząc przed burzą, rozpędziwszy koni, razem się zjechali z impetem wielkim na wąską drogę i ledwo bryczek nie zgruchotali, i często sam woźnica brodaty a do tego napity dobrze był, w wielkim niebezpieczeństwie, aleśmy jego utrzymywali za sążniste pejsa.

Te i tym podobne zdarzenia, smutki i pociechy, któreśmy dla miłości Boga doświadczyli w czasie naszej podróży, ze szczególną strażą św. Aniołów Stróżów, którychśmy za patronów obrali, z pociecha wspominając, wreszcie po mnogich trudach, troskach, po burzach, przygodach, dość szczęśliwie na nocleg stanęliśmy w Brodach ${ }^{51}$.

51 Wygnaniec z Białej Rusi. Część pierwsza przez J.X. Jana N. Gallicza, Kapłana Tow. J. pisany, w Roku Pańskim 1821, w Montmorillionie, we Francji, rękopis Archiwum Prowincji Polski Południowej Towarzystwa Jezusowego w Krakowie, sygn. 662 (,utwór literacki pisany ręką ojca W. Baudissa TJ jako magistra Konwiktu Tarnopolskiego”), s. 66-69.

Wrocławskie Studia Wschodnie 23, 2019

(C) for this edition by CNS 
Inna zupełnie jest wrażliwość Niemcewicza na komory i kordony graniczne. Bierze się ona z tradycyjnych, jeszcze sarmackich, przekonań, że wypracowane na przestrzeni wieków obrysy wschodnie państwa polskiego nie łączą etnosów, nie budują wielokulturowego dialogu pogranicznego, ale siecią twierdz i strażnic (mit antemurale christianitatis) oddzielają Polaków, czy w ogóle Europejczyków, od „wschodniej dziczy”. Dlatego nie może on zaakceptować sytuacji, gdy w wyniku podziałów rozbiorowych po tej samej stronie kordonu zamieszkują ludzie cywilizowani (nowocześni, ,polerowani”) oraz nieokrzesani barbarzyńcy, których żywotność w warunkach podboju i poszerzania swojego dominium jest wyjątkowa. Tym samym struktura etniczna strzeżona tradycyjnymi granicami uległa znaczącej destrukcji. Nie rozkoszuje się więc pamiętnikarz krajobrazem stepowym, jak będą to czynić romantycy, ani wyludnionymi przestrzeniami, nad którymi krążą wygłodniałe drapieżniki. Zdehumanizowane ukraińskie „pustynie” kojarzą mu się z zapóźnieniem i pierwotnością. Nazywa je „dziczą tatarską”, ultima Thule. Jedynym znakiem ludzkiej obecności na tych terenach, jak podkreśla, są porozrzucane w dużych odległościach kurhany ${ }^{52}$ i przystanki pocztowe zasiedlone przez współczesnych troglodytów:

Smutną jest jednostajność czczych pól, żadnym jeziorem, lasem, żadnym nawet gajem nieożywionych. Dropie, pardwy, bociany, żurawie, prawdziwymi są step tych właścicielami. Na pocztach tylko ludzkie stworzenia, i to ledwie że ludzie. Jurty, nazwane domami pocztowymi, są to niskie pod trzciną lepianki. Nie znajdzie w nich wędrownik ni pokarmu, ni ochłody, ni spoczynku; odstręczają od zatrzymania się sama nieczystość i zaduch. Trzymający pocztę pojemszczyki sami nie mieszkają w tych jurtach, wierników tylko trzymając. Tam, w niskiej izbie, widzisz w około twarde prycze, na których rozciągnięci chrapią jemszczyki; nie wstają jak do jedzenia lub do wożenia. W kącie tli się ognisko podsycane suszonym gnojem lub trzciną. Przy nim zamurzane, zabłocone straszydło, do kobiety podobne nieco. W całym tym społeczeństwie, jedne tylko czyste stworzenie, i to jest kot. W równie nędznej naprzeciw izdebce śpi, na brudnym kocu, pristawa czyli pisarz albo wiernik, zapisujący podorożne i biorący za progon zapłatę. Zdaje się że spanie jest ulubionym i jedynym tworów tych zatrudnieniem. I czymże istność ze czczym umysłem, ręczną niezatrudniona pracą, bawić się może? Nic bardziej jak życie takie do bydlęcego stanu nie przybliża człowieka. Nieraz wieczorem zastawałem jemszczyków

52 Do takiej hierarchizacji przestrzeni piękny dodaje jednak opis stepów ukraińskich. Oto jego fragment: „W krainie, która jest dziś prawie, jaką była przed wiekiem, jaką była przed tysiącem wieków, jaką była może w dniu stworzenia, kiedy wyszła z Wszechmocnego dłoni, nie już natężenie umysłu, lecz głębokie dumanie ogarnia duszę człowieka. Nową jest i zajmującą rzeczą widzieć kraj taki, wspomnieć, że był czas, gdzie niwy dźwigające dzisiaj ogromny Paryż, zamożny Londyn, były także stepami. Wszystko w tej obszernej samotności, sama nawet cisza jest uroczystą i przejmującą. Tło niebios, czyste jak błękit lazuru, lub powleczone gdzieniegdzie runami goniących się białych obłoków. Spuścisz oczy wkoło siebie, nie uderza cię żaden twór ludzki, żadne dzieło pracy człowieka. Nietknięte nigdy ręką ludzką błonia, okrywa bujna wysoko wznosząca się trawa; nieraz przebijają się przez nią nieznanych kwiatów rubiny, szafiry, topazy. Krzyk orłów, lot wędrownego ptastwa, rącze dzikich zwierząt gonitwy, często samotne przerywają dumania" - Juliana Ursyna Niemcewicza podróże..., s. 308.

Wrocławskie Studia Wschodnie 23, 2019

(C) for this edition by CNS 
tych przy jedzeniu. Siedziały wkoło ogromne ich postacie już w wieku podeszłe, w podartych łachmanach, najczęściej boso, ze splecionymi w kołtun brodami, jadły ulubioną sobie potrawę, to jest rzodkiew lub sczypiór ze solą i chlebem, z lepszym może apetytem i weselej, niż my możni nieraz za godowymi stołami. Ach, tu to widzieć można najrzeczywiściej, jakie ogłada społeczności czyni różnice, między człowiekiem a człowiekiem! ${ }^{53}$

Niemcewicz nie może się pogodzić z faktem, że ta sama granica spina wspólną przestrzenią z jednej strony ludzi, o których bóstwa i królowie zapomnieli, z drugiej - Polaków. Innym razem oburza się na myśl o podziałach rozbiorowych i przypomina linię graniczną Rzeczypospolitej, za którą w kierunku Azji rozpoczynały się Dzikie Pola:

O werstę za Nowomirhorodem zaczyna się dawna Polska, w miejscu Złotopol zwanym. Jak zaraz odmienna rzeczy postać! Kraj nasz, jeden z najmniej zaludnionych w Europie, w porównaniu z dziczyzną przez którą tak długo jechałem, zdaje się napełniony ludu rojami. Jak mile zastanawiały się oczy nad uprawnymi rolami; zamiast gołego bez końca widokresu, wiodły się po porozrzucanych, acz rzadko, włościach, gajach, łąkach, jeziorach ${ }^{54}$.

\section{Spowiedź obywatelska}

Niemcewicz uchodził za największego, obok Kołłątaja, nieprzyjaciela poczynań Katarzyny II. Nakładały się na to uprzedzenia kulturowe. Skłonny był twierdzić, że niewola narzucona Polakom przez któryś z krajów europejskich byłaby znośniejsza niż rosyjska. Jak pisał już po pierwszym rozbiorze, nie do wyobrażenia jest sytuacja, aby cała Polska znalazła się ,,pod jarzmem moskiewskim”, „azjatyckim, barbarzyńskim"55. Na lada wzmiankę o Rosjanach i ich zwierzchnikach kotłowało się w duszy Niemcewicza do tego nawet stopnia, że czuł się zobowiązany wyspowiadać z grzesznych (jak mniemał) myśli o nich. Wymowny i równocześnie zabawny jest tu fragment pamiętnika opisujący jego wielkopostną konfesję. Wyznaniu win nie towarzyszy tu skrucha, lecz oburzenie na uwagi spowiednika, z którym pamiętnikarz rozmawiał przy konfesjonale w Rzymie:

Nie opisuję wiadomych wszystkim obrządków Watykanu w Wielkim Tygodniu, są one wspaniałe i tkliwe, lecz jakże zgorszony byłem, widząc, jak czysta religia Chrystusa znieważaną była światowymi widokami sług Jego: czyniąc zadosyć powinnościom chrześcijańskim poszedłem do spowiedzi, do penitencjariusza polskiego, eks-jezuity; z łagodnością słuchał wyznań moich, lecz gdym mu powiedział, że przeklinałem nieraz carową i targowiczanów, dopiero surowo karcić mnie zaczął, nie o grzech przeklinania, lecz o osobę, na którą miotane były. „Nie uważaszże - rzecze - że wielka ta monarchini jedną jest z panów europejskich, która zakonowi Societatis Jezu dała przytułek i wsparcie, nie wątpić, że do zabranych dziś

53 Ibidem, s. 329.

54 Ibidem, s. 331. O tej granicy pisze także arcybiskup mohylewski Ignacy Hołowiński w Pielgrzymce do Ziemi Świętej, Petersburg 1853, s. 2.

55 J.U. Niemcewicz, Pamiętniki czasów moich..., t. 1, s. 153.

Wrocławskie Studia Wschodnie 23, 2019

(C) for this edition by $\mathrm{CNS}$ 
województw monarchini zakon nasz wprowadzi”; miałemże wchodzić w dysputę na spowiedzi, zamilkłem, pomyślawszy sobie, że sprawiedliwość, że obywatelstwo, że miłość, litość nad ojczyzną niczym są, a wszystkim jest rozkrzewienie i potęga tego prawdziwie niebezpiecznego zakonu jezuitów ${ }^{56}$.

\section{Bibliografia}

Bolecki W., Julian Ursyn Niemcewicz (1758-1841), [w:] Pisarze polskiego oświecenia, red. T. Kostkiewiczowa, Z. Goliński, t. 2, Warszawa 1994, s. 387-413.

Chachaj M., Pamięć i zapomnienie - uwagi na marginesie „Podróży historycznych po ziemiach polskich między rokiem 1811 a 1828 odbytych" Juliana Ursyna Niemcewicza, [w:] Tożsamość. Kultura. Nowoczesność, t. 2. Czas, pamięć, red. B. Morzyńska-Wrzosek, M. Kurkiewicz, I. Szczukowski, Bydgoszcz 2017, s. 51-62.

Cieński A., Pamiętnikarstwo polskie XVIII wieku, Wrocław 1981.

Custine A.L.L. markiz de, Listy z Rosji. Rosja w 1839 roku, przeł. K. Czermińska, Londyn-Warszawa 1988.

Czartoryski A.J., Żywot Juliana Ursyna Niemcewicza, Berlin-Poznań 1860.

Dąbrowicz E., Galeria ojców. Autorytet publiczny w literaturze polskiej lat 1800-1861, Białystok 2009.

Juliana Ursyna Niemcewicza podróże historyczne po ziemiach polskich, między rokiem 1811 a 1828 odbyte, Paryż-Petersburg 1858.

Między rozpacza i nadzieją. Antologia poezji porozbiorowej lat 1793-1806, oprac. M. Nalepa, Kraków 2006.

Niemcewicz J.U., Pamiętniki czasów moich, oprac. J. Dihm, t. 1-2, Warszawa 1957.

Niemcewicz J.U., Podróże po Ameryce 1797-1807, z rękopisu wydała, wstępem i objaśnieniami opatrzyła A. Wellman-Zalewska, red. E. Kipa, Wrocław-Warszawa 1959.

Panas W., O pograniczu etnicznym w badaniach literackich, [w:] Wiedza o literaturze i edukacja, red. T. Michałowska, Z. Goliński, Z. Jarosiński, Warszawa 1996, s. 605-613.

Podemski K., Socjologia podróży, Poznań 2004.

Słownik geograficzny Królestwa Polskiego i innych krajów słowiańskich, t. 13, red. F. Sulimierski, B. Chlebowski, W. Walewski, Warszawa 1893.

Uliasz S., Literatura Kresów - kresy literatury, Rzeszów 1994.

Wieczorkiewicz A., Apetyt turysty. O doświadczaniu świata w podróży, Kraków 2008.

Winiarski J., W przestrzeni kulturowej poezji polskiej (pejzaże antropologiczne z wieków dawnych i współczesne). Studia i szkice, Kraków 2017.

Wygnaniec z Białej Rusi. Część pierwsza przez J.X. Jana N. Gallicza, Kapłana Tow. J. pisany, w Roku Pańskim 1821, w Montmorillionie, we Francji, rękopis, Archiwum Prowincji Polski Południowej Towarzystwa Jezusowego w Krakowie, sygn. 662.

Zając G., Czuły weredyk. Twórczość poetycka Juliana Ursyna Niemcewicza, Kraków 2015.

56 Ibidem, t. 2, s. 66. 


\title{
Государственные, народные и культурные границы в мемуарной прозе Юлиана Урсын-Немцевича
}

\author{
Резюме
}

Уроженец деревни Скоки Брест-Литовского округа Юлиан Урсын-Немцевич в жизни принадлежал к группе людей, необыкновенно интересующихся миром, следствием чего были его многочисленные путешествия по Европе и Америке. Он странствовал, добровольно или под принуждением, по Старому Свету от Сицилии до Скандинавии и от Лондона до Петербурга, совершил экскурсию на Ниагарский водопад, посетил индейские и негритянские деревни Земли Вашингтона и потому, что не чувствовал себя спокойно при мысли, что лучше познал чужие края, чем землю отцов, в 1811 году предпринял цикл исторических путешествий по Польше, в которых, кроме туристических целей, хотел проявить свой гражданский протест против установления в 1772 году границ государствами-захватчиками на земле Речи Посполитой Обоих Народов. Постоянно в сообщениях (парламентарных, корреспондентских и литературных) он протестовал против административной демаркационной линии, с трудом её пересекал, придерживаясь принципа, что границы Польши раз и навсегда установили пястовские и ягеллонские правители. Он не соглашался с любыми их изменениями и ограничениями и не признал утрату государственных границ в 1795 году. Более всего он сопротивлялся нарушению границ, разделяющих первоначально Варшавское Княжество, а потом Королевство Польское и Российскую империю.

\section{State, national and cultural borders in Julian Ursyn Niemcewicz's memorial prose}

\author{
Summary
}

Born in Skoki, near Brest, Julian Ursyn Niemcewicz was part of a group of people in the Enlightenment period who were exceptionally interested in the world, which led to his numerous travels across Europe and America. He travelled, voluntarily or under coercion, across the Old Continent, from Sicily to Scandinavia, and from London to St. Petersburg; he went on a trip to Niagara Falls, visited Indian and Negro villages in the Washington Land, and, feeling uncomfortable with the idea that he had got to know foreign lands better than his fatherland, in 1811 he embarked on a series of historical journeys across Poland, during which, in addition to pursuing tourist goals, he wanted to manifest his civic objection to the partition of the PolishLithuanian Commonwealth in 1772. In his accounts (memoirs, letters and literary works) he consistently challenged administrative demarcation lines, crossing them with great difficulty, faithful as he was to the belief that Poland's borders had been set once and for all by rulers from the Houses of Piast and Jagiellon. He accepted no changes of the borders and reduction of the country's territory, and obviously did not acknowledge the loss of statehood in 1795 . What became the most problematic for him was the crossing of the border separating first the Duchy of Warsaw and then the Kingdom of Poland from the Russian Empire. 